\title{
Inter-annual reproductive trait variation and spawning habitat preferences of Engraulis ringens off northern Chile
}

\author{
Variaciones interanuales en aspectos reproductivos y preferencias por el \\ sitio de desove en Engraulis ringens del norte de Chile \\ Gabriel Claramunt ${ }^{1}$, Leonardo R. Castro², Luis A. Cubillos ${ }^{3}$, \\ Hans-Jürgen Hirche ${ }^{4}$, Graciela Perez ${ }^{5}$ and Mauricio Braun ${ }^{6}$
}

\author{
${ }^{1}$ Departamento Ciencias del Mar, Universidad Arturo Prat, Casilla 121, Iquique, Chile. gclaramu@unap.cl \\ ${ }^{2}$ Laboratorio de Oceanografía Pesquera y Ecología Larval, Centro FONDAP-COPAS y Departamento de Oceanografía, \\ Facultad de Ciencias Naturales y Oceanográficas, Universidad de Concepción, Casilla 160-C, Concepción, Chile \\ ${ }^{3}$ Laboratorio de Evaluación de Poblaciones Marinas (EPOMAR), Departamento de Oceanografía, Universidad de Concepción, \\ Casilla 160-C, Concepción, Chile \\ ${ }^{4}$ Alfred Wegener Institute for Polar and Marine Research, Columbusstrasse D-27568, Bremerhaven, Germany \\ ${ }^{5}$ Instituto de Fomento Pesquero, Barrio Industrial, Sitio $N^{\circ}$ 2, Casilla 170, Iquique, Chile \\ ${ }^{6}$ Instituto de Fomento Pesquero, Blanco 839, Casilla 8-V, Valparaíso, Chile
}

\begin{abstract}
Resumen.- A lo largo del Sistema de la Corriente de Humboldt, la anchoveta (Engraulis ringens) se distribuye entre los $4^{\circ} \mathrm{S}$ y $42^{\circ} \mathrm{S}$. Las condiciones ambientales difieren notablemente tanto entre las zonas de desove y las estaciones del año. Por lo tanto, diferentes tácticas reproductivas se esperan en respuesta al medio ambiente. En este estudio se utilizó la información proveniente de cruceros para la aplicación del Método de Producción Diaria de Huevos (MPDH) para estudiar la variabilidad latitudinal e interanual de los parámetros reproductivos de las poblaciones de E. ringens en la zona norte $\left(18^{\circ} 20^{\prime}\right.$ a $\left.26^{\circ} 00^{\prime} \mathrm{S}\right)$ y sur $\left(33^{\circ} 00^{\prime}\right.$ a $\left.41^{\circ} 30^{\prime} \mathrm{S}\right)$ de Chile. El objetivo principal es investigar las potenciales preferencias por ciertos rangos de temperatura y concentración de clorofila- $a$ en el hábitat de desove y los cambios en el potencial reproductivo y tamaño de los huevos de anchoveta en respuesta a las condiciones del hábitat, en especial a la temperatura. Los resultados muestran que la temperatura no es una variable relevante del medio ambiente para determinar la posición geográfica de las zonas de desove de E. ringens. Altas concentraciones de clorofila sería la variable seleccionada para los cambios en la posición de las áreas de desove. Se postula que en lugar de preferir cierto rango de temperatura, anchoveta acomoda los productos del desove de acuerdo a las condiciones predominantes del medio ambiente (ej. tamaño del huevo, fecundidad) y esta respuesta sería en la escala de la frecuencia de desove, es decir, semanas.
\end{abstract}

Palabras clave: Áreas de desove, producción de huevos, fecundidad, anchoveta

\begin{abstract}
Along the Humboldt Current System, the anchoveta (Engraulis ringens) is distributed between $4^{\circ} \mathrm{S}$ and $42^{\circ} \mathrm{S}$. Environmental conditions differ markedly both between spawning areas and seasonally. Hence, different reproductive tactics are expected in response to the environment. Here we used information from Daily Egg Production Method surveys to study latitudinal and interannual variability of the reproductive parameters in stocks of $E$. ringens from the northern $\left(18^{\circ} 20^{\prime}\right.$ to $\left.26^{\circ} 00^{\prime} \mathrm{S}\right)$ and southern $\left(33^{\circ} 00\right.$ to $\left.41^{\circ} 30^{\prime} \mathrm{S}\right)$ Chilean coast. The main goal was to investigate potential preferences for temperature and chlorophyll concentration in the spawning habitat and changes in the reproductive potential and egg size of anchoveta in response to the prevalent habitat conditions, mainly temperature. Temperature was not a relevant environmental variable to determine geographical position of the spawning areas in $E$. ringens. High chlorophyll-a concentration appears as the selected variable for spawning habitat. According to our results, the interannual changes in the body weight-fecundity relationship are related to the temperature of the environment, which affects the egg size. We postulate, therefore, that instead of searching for certain temperatures, anchoveta accommodate their offspring characteristics according to the prevalent environment (e.g., egg size, fecundity). The response of the reproductive system to temperature might be in the scale of spawning frequency, i.e., weeks.
\end{abstract}

Key words: Spawning areas, egg production, fecundity, anchoveta 


\section{INTRODUCTION}

Along the Humboldt Current System, the anchoveta, Engraulis ringens Jenyns, 1842, is distributed mainly between $4^{\circ} \mathrm{S}$ and $42^{\circ} \mathrm{S}$ (Serra 1986). Castro et al. (2009) distinguished three major stocks: the largest off northerncenter Peru, a mid-sized one off southern Peru-northern Chile, and the smallest off central Chile (see also Valdivia et al. 2007). The occurrence of upwelling changes from mostly continuous in northern Chile to a more seasonal pattern in central Chile (Thiel et al. 2007, Sobarzo et al. 2007). Off central Chile, the spawning season is in wintertime, when temperatures are lower, upwelling events are scarce and wind induced turbulence in the water column is higher than in northern Chile (Castro et al. 2009). On an interannual scale, the physical forcing is associated with the El Niño Southern Oscillation (ENSO) cycle (Yañez et al. 2008). The persistence of Engraulis ringens in these highly variable environments is probably a result of a complex set of behavioral and biological traits that form part of the adult reproductive strategy. Therefore, different reproductive tactics are expected in response to the differences in environmental conditions along the species range and in an interannual scale.

Wright \& Trippel (2009) report that unlike many other branches of evolutionary ecology, fishery science theory has tended to consider offspring survival (recruitment) in relation to a population's peak or duration of egg production rather than the reproductive success of individual parents. As such, fishery science has tended to focus on the role of the environment in influencing year-class variation rather than the life history traits that fish have evolved to reproduce successfully under these varying conditions. In the case of Engraulis ringens from the Chilean coast, studies during recent years have determined how the early life stages of this species cope with variations in environmental conditions (Castro et al. 2000, 2009, Hernández \& Castro 2000, Llanos-Rivera \& Castro 2004, 2006). In particular, it has been shown that egg size, larval length at hatching and yolk sac volume of recently hatched larvae increase with latitude and instantaneous yolk sac larval growth rates vary between populations (Llanos-Rivera \& Castro 2006). Leal et al. (2009) found that the oocyte size is smaller and fecundity is higher in northern population as compared with the population off central Chile, concluding that the environmental temperature could play an important role in oocyte number and size regulation.

Most of the recent studies assessing potential reproductive trait variations of anchoveta have focused on either seasonal or latitudinal variations along the species range. Less attention has received the study of the potential relationship between these traits and environmental fluctuations within each population distribution range at the inter-annual time scale. Along the Chilean coast, the Daily Egg Production Method (DEPM) has been utilized for several years to estimate spawning biomass in the northern and central Chile $E$. ringens populations. One of the great advantages of this method is that in addition to abundance estimates it provides valuable information about the reproductive biology of the stocks through intensive sampling of the ichthyoplankton and adult females. This information may be utilized to study maternal effects as it includes datasets of large sample size, large spatial coverage and almost unchanged repetitive sampling design over several years that allow interannual and inter population comparisons.

In the present study, we analyzed the interannual variability in the reproductive parameters of $E$. ringens from the population located in northern Chile, to determine potential changes in the characteristics of the reproductive output (spawning habitat preferences, egg size, fecundity and daily spawning fraction) in response to the prevalent habitat conditions. As indicators of habitat condition we utilized sea surface temperature and phytoplankton biomass (satellite derive chlorophyll-a). Temperature is usually used as a proxy for habitat condition in coastal upwelling areas, it is a common variable available from all surveys carried out in the different spawning areas, and also it is an environmental variable known to affect reproductive parameters. Phytoplankton biomass (chlorophyll-a concentration) distribution is here utilized to explore whether it might have a relationship with the selection of the main female spawning sites (as depicted by the largest egg abundances) within the spawning area. Temperature and phytoplankton biomass abundance may co-vary in some environments (depending on the time and space scales explored). However, this potential relationship may not always hold in upwelling areas since the highest chlorophyll values are usually reached not at the lowest temperature zones (i.e., in recently upwelled water) but in nearby areas where the upwelled waters rich in nutrients have reached some stability after few days at the photic zone. When reproductive and environmental data was available, we expanded our analyses to the southern $E$. ringens population located in central Chile. These complementary analyses in some cases allowed to broadening the range of environmental values over with 
the reproductive traits were assessed and, in other cases were utilized for inter-population comparisons in traits response to different conditions.

We use the term selection or habitat preference as usual in the related literature of characterization of the spawning habitats. According to SPACC Meeting (Castro et al. 2005): small pelagic fish are indeterminate spawners that spawn repeatedly over a protracted reproductive season, and often in a variety of environments. The number of eggs produced per spawning season depends both on energy (lipid) reserves and the quantity and quality of food available during the season, and hence is not fixed at the beginning of the reproductive season. Additionally, small pelagic fish can cease spawning and reabsorb their eggs if conditions become unfavourable, a process known as atresia. Given the above, weak or no selection for temperature/salinity optima or for other environmental proxies could perhaps be expected. A disadvantage of this approach is that temperature/salinity or other variable may not necessarily be important per se for spawning habitat selection, but may be proxies for other variables (e.g., productivity) that may be more relevant to spawning habitat selection (Castro et al. 2005).

\section{Materials AND METHODS}

In Chile, spawning stock biomass estimates for Engraulis ringens have been obtained by conventional application of DEPM in the two main spawning areas. In northern Chile (18²0’S-265), DEPM was applied in 1995, 1996

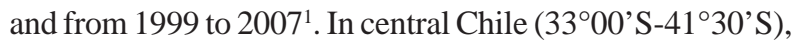
DEPM was applied from 2002 to $2007^{1}$. Plankton stations were distributed regularly in a sampling grid where eggs were collected in vertical hauls of Pairovet nets $\left(0.05 \mathrm{~m}^{2}\right.$ and $0.150 \mathrm{~mm}$ mesh size). The sampling scheme was based on transects spaced approximately ten nautical miles apart and stations located at five-nautical-mile intervals on each transect. In addition, purse-seine boats were used for annual adult surveys, which sampled a minimum of 30 females in each of 32 hauls (Table 1).

\section{SPAWNING AREA}

A single factor quotient analysis was utilized as an exploratory data analysis tool to describe the potential relationship between egg abundance and temperature (Van der Lingen et al. 2001, Drapeau 2004). First, the seawater temperature data set (temperature at $10 \mathrm{~m}$ depth) collected
Table 1. Number of hawls and total number of females sampled in the DEPM surveys and used for histological analysis. All surveys are centered in August / Número de lances y número de hembras muestreadas en los cruceros y las utilizadas para análisis histológico. Todos los cruceros están centrados en agosto

\begin{tabular}{ccccc} 
& \multicolumn{2}{c}{ Northern Chile } & \multicolumn{2}{c}{ Southern Chile } \\
\cline { 2 - 5 } Year & Hawls & Females & Hawls & Females \\
\hline 1992 & 48 & 1440 & - & - \\
1995 & 40 & 1177 & - & - \\
1996 & 32 & 927 & - & - \\
1997 & 60 & 1800 & - & - \\
1999 & 51 & 1530 & - & - \\
2000 & 92 & 1800 & - & - \\
2001 & 60 & 1800 & - & - \\
2002 & 60 & 1800 & 32 & 1384 \\
2003 & 60 & 1800 & 78 & 2620 \\
2004 & 55 & 1651 & 45 & 1456 \\
2005 & 60 & 1799 & 40 & 1147 \\
2006 & 42 & 1260 & - & - \\
2007 & 55 & 1645 & 50 & 1991 \\
\hline
\end{tabular}

over the entire region each year was divided in equally temperature ranges classes and the percentage frequency of occurrence $\left(p_{i}\right)$ of each class (i) within the entire area was determined as:

$$
p=\frac{p_{i}}{\sum_{i=1}^{l} p_{i}} * 100
$$

The same procedure was applied to egg abundance data, with the number of eggs associated with each temperature class $\left(h_{i}\right)$, expressed as a percentage of the total number of eggs collected during the survey:

$$
h=\frac{h_{i}}{\sum_{i=1}^{I} h_{i}} * 100
$$

Finally the quotient was estimated as

$$
Q=\frac{h}{p}
$$

Confidence intervals of the null hypothesis of even distribution were computed by a resampling procedure

${ }^{1}$ Final reports are available online at $<$ http://www.fip.cl $>$ 
(999 times) in order to test for the significance of quotient values larger or smaller than one according to Bernal et al. (2007), through an implementation of a routine in Visual Basic (Macro in Microsoft Excel). If the quotient value is significantly $>1$ or above the upper confidence interval, fish are assumed to select that variable range for spawning, and if it is significantly $<1$ or below the lower confidence interval the variable range is assumed to be avoided (Van der Lingen et al. 2001, Bernal et al. 2007). For the northern and southern zone intervals of 0.2 and $0.5^{\circ} \mathrm{C}$ were used respectively, because of the range of temperatures on the surveys.

A quotient analysis was also carried out in the northern area utilizing chlorophyll-a satellite derived data. In this area, monthly chlorophyll (Chl-a) data (years 2002 to 2011) were obtained from the MODIS-Aqua sensor, produced and distributed by Ocean Color Data Processing System², with a resolution of 10x10 nm in a hierarchical data file and represent a global coverage for each month. Due to the high asymmetry, Chl-a data were transformed by using natural logarithm. The quotient analyses with chlorophylla were carried out following the same procedures utilized for the temperature analyses.

Egg density (number by $0.05 \mathrm{~m}^{2}$ ), latitude, longitude, temperature (10 m depth) and satellite Chl-a (ln transformed) data were used to fit a GAM model as a complement of the quotient analysis in order to assess the potential influence of this set of parameters on the selection of spawning sites by E. ringens females in northern Chile. For the selection of the GAMs smoothing predictors we applied the methodology proposed by Wood \& Augustin (2002), using the 'mgcv' library in the R statistical software (R Development Core Team 2004). GAMs produced smoothed fits for each environmental predictor.

\section{Batch FECUNDITY}

From both spawning areas, the number of eggs spawned per batch (batch fecundity; $F$ ) was estimated by applying the gravimetric method on hydrated females (Hunter et al. 1985), which excludes females with new postovulatory follicles as determined from histology. The oocyte countings were carried out on three ovary sections (front, medium and posterior) of about $0.2 \mathrm{~g}$ each, from which at least 100 hydrated oocytes were observed. Batch fecundity was estimated as the average of these three

${ }^{2}<$ http://oceancolor.gsfc.nasa.gov> subsamples. The same procedures were utilized in the southern spawning zone.

\section{OocYTE AND EgG SIZE}

From 2000 to 2003 and in 2007, anchoveta eggs collected in northern Chile were measured (major and minor axe) utilizing an image analysis software Image $J^{3}$. The volume was estimated assuming the egg to be of ellipsoid shape $(\mathrm{V}=4 / 3 \pi \cdot \mathrm{a} \cdot \mathrm{b} \cdot \mathrm{c}$, being $\mathrm{a}, \mathrm{b}$ and $\mathrm{c}$ the radio of the ellipsoid).

\section{SPAWNING FRACTION}

The daily spawning fraction $(S)$ of E. ringens (i.e., proportion of female fish that reproduce daily) in each DEPM application was estimated from the histological preparation of the female ovaries by identifying and classifying postovulatory follicles (POF) into daily cohorts. POFs were classified in 0-, 1- and 2-days, where POF 0- day means that spawning occurred less than $9 \mathrm{~h}$, POF 1- day from 9 to $33 \mathrm{~h}$ and POF 2- day from 33 to $56 \mathrm{~h}$ from the spawning peak (we used 23:00 h), according to the criteria of Hunter \& Macewicz (1985). The mean of $S$ was estimated using females with POF 1- day and 2- day (POF 1+2), thus increasing the sample size and reducing the variance (Alheit et al. 1984). These same procedures were utilized for the southern spawning population.

\section{RESUlTS}

\section{SPAWNING AREA}

In the northern zone a high variability in both location (geographical position) and extent (area covered by positive stations) of the spawning area was observed (Fig. 1). In terms of locations, changes occurred in latitude and coast-ocean directions. In some years the eggs were distributed near the coast (e.g., 2001, 2003 and 2004), in contrast to years with a more oceanic distribution (2000, 2002, 2005). Latitudinally within the spawning area in northern Chile, in some years the main spawning zones were north of $20^{\circ} \mathrm{S}$ (e.g., 2007), while in others years they were south of $21^{\circ} \mathrm{S}$ (e.g., 2001, 2005).

In the northern spawning area off Chile, the mean temperature at $10 \mathrm{~m}$ depth throughout the years studied was $15.9^{\circ} \mathrm{C}(\mathrm{SD}=0.997)$ (Fig. 2). In 1997 the influence of a strong El Niño event was clearly observed as revealed by 


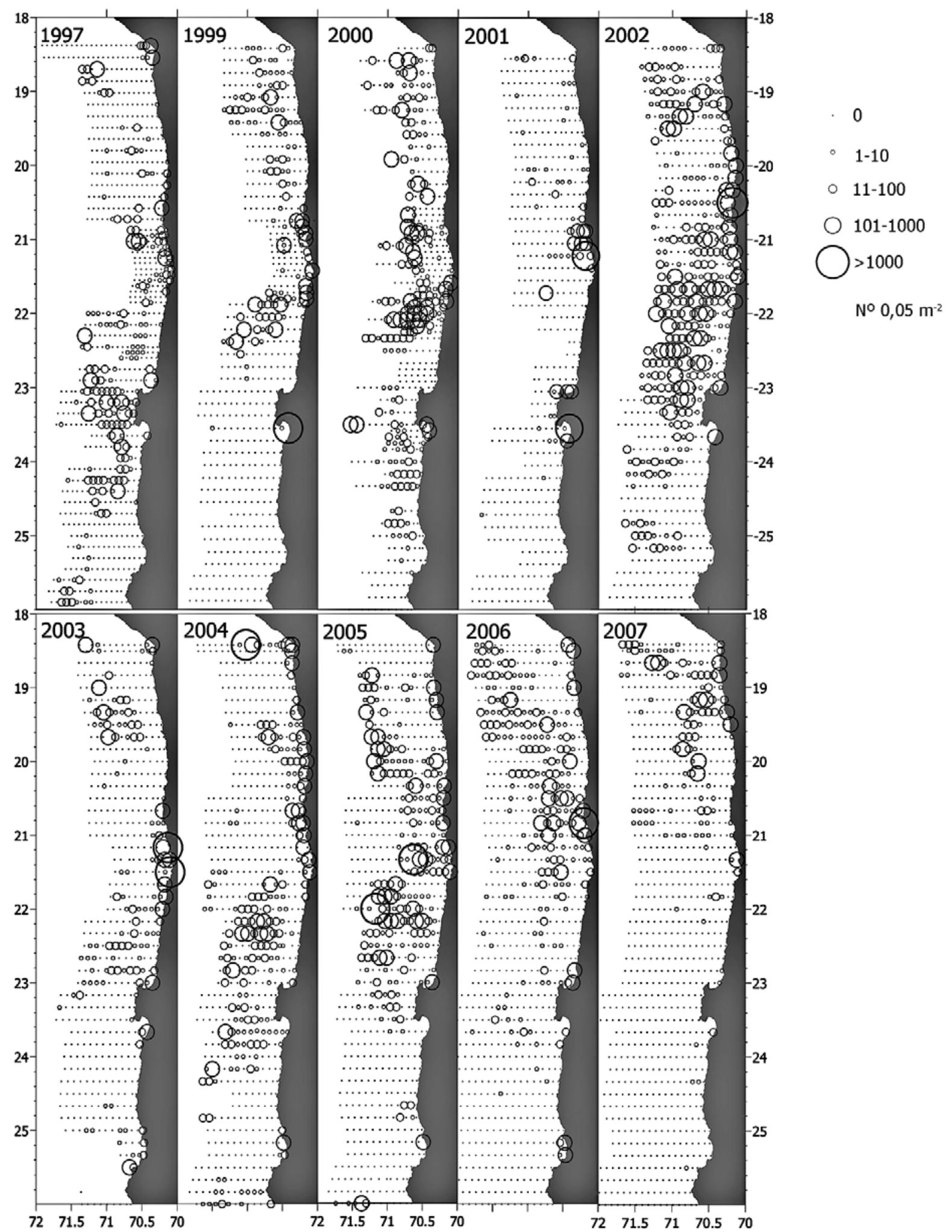

Figure 1. Spawning areas of anchoveta from northern Chile. Size of the circles represents eggs density / Áreas de desove de anchoveta en el norte de Chile. Tamaño de los círculos representan la densidad de huevos 

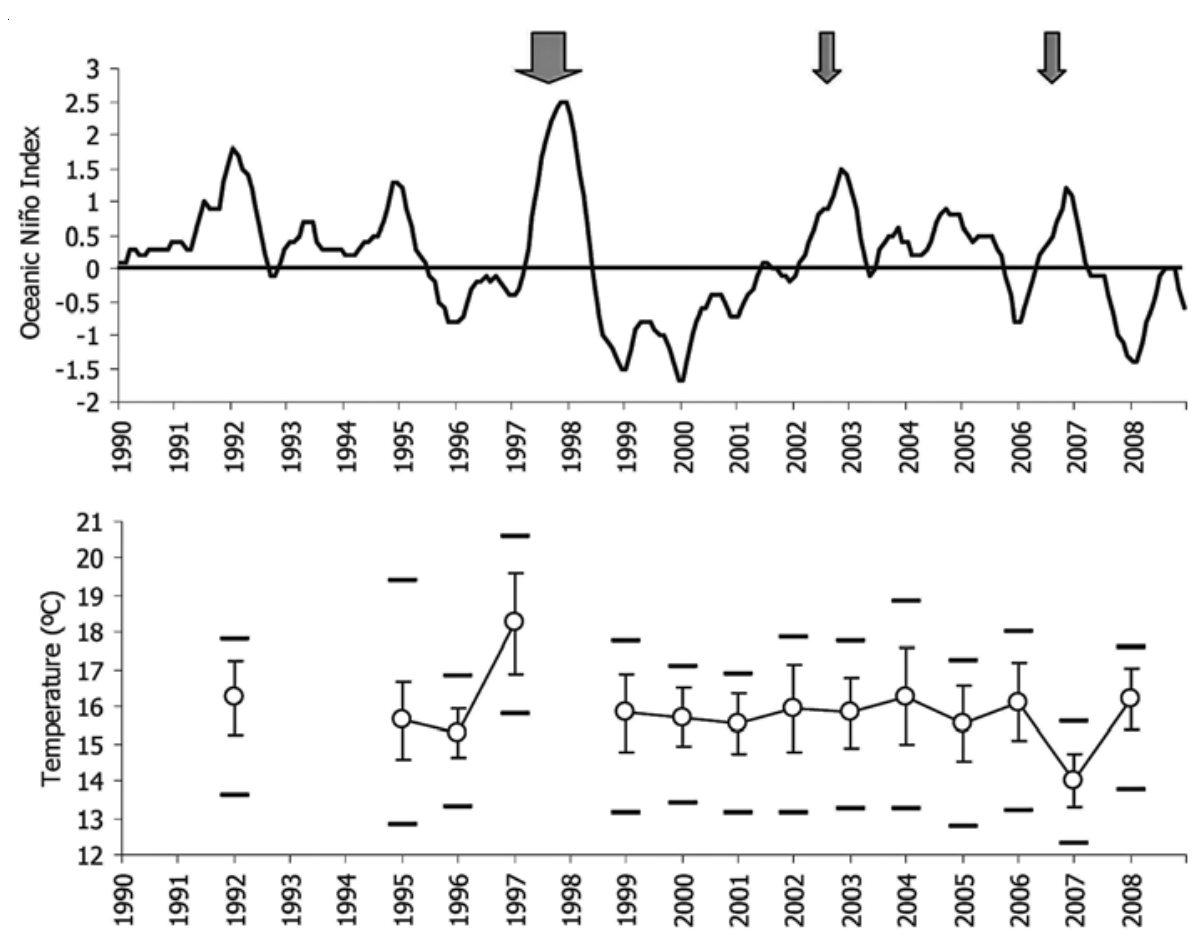

Figure 2. Up: Warm and cold episodes based on the Oceanic Niño Index (ONI) anomalies in the Niño 3.4 region $\left(5^{\circ} \mathrm{N}-5^{\circ} \mathrm{S} ; 120^{\circ}-170^{\circ} \mathrm{W}\right)$, based on the 1971-2000 base period (*). Arrows indicate El Niño events (1997, 2002 and 2006). Bottom: Mean temperature (10 m depth) of each survey in northern Chile. Vertical lines: standard deviation. Horizontal lines: Minimum and maximum / Arriba: Episodios cálidos y fríos basados en las anomalías del Indice Oceánico de El Niño (ONI) en la región Niño $3.4\left(5^{\circ} \mathrm{N}-5^{\circ} \mathrm{S} ; 120^{\circ}-170^{\circ} \mathrm{W}\right)$, con período base de $1971-$ $2000(*)$. Flechas indican eventos El Niño (1997, 2002 y 2006). Abajo: Temperaturas medias (10 m profundidad) de cada crucero en el norte de Chile. Líneas verticales: Desviación estándar. Líneas horizontales: Mínimo y máximo

$(*)$ : <http://www.cpc.ncep.noaa.gov/products/analysis_monitoring/ensostuff/ensoyears.shtml>

a temperature mean of $18.3^{\circ} \mathrm{C}(\mathrm{SD}=1.36)$ during the survey. In contrast, the year 2007 was under La Niña influence with a mean survey temperature of $14^{\circ} \mathrm{C}(\mathrm{SD}=$ 0.73).

The quotient analysis shows different situations for every year. In Figure 3 only three years of contrasting environmental conditions (El Niño; La Niña; Neutral ENSO) are presented (for graphic simplicity) for the northern and southern spawning areas. A shift in the frequency of observed temperatures of the water column over the area were observed among years in both areas (from higher temperatures in El Niño to mid temperatures in Neutral ENSO and to lower temperatures during La Niña), more particularly evident in the northern spawning area. The quotient analyses for the northern area (intervals of $0.2^{\circ} \mathrm{C}$ ) indicate that under the influence of $\mathrm{El}$ Niño (1997) a significant preference for a narrow range of temperatures of $19.0-19.2^{\circ} \mathrm{C}$, while in normal years (Neutral ENSO, 2002) significant association are found at 15.0-
15.2 and $16.6-16.8^{\circ} \mathrm{C}$. In colder years (2007, La Niña) a significant relationship for 14.8 to $15.2^{\circ} \mathrm{C}$ was observed. Accordingly, potential temperature associations during these very contrasting years changed also following the variations in environmental conditions. All years grouped (1992 to 2007) shows significant peaks at 15.0-15.2, 1616.2 and $19-19.2^{\circ} \mathrm{C}$ (Fig. 3, bottom panels). For southern zone the quotient analysis (every $0.5^{\circ} \mathrm{C}$ ) shows a significant peak at $11.0-11.5^{\circ} \mathrm{C}$ in 2002 and $11.5-12.0$ in 2005. There are no significant preferences in 2007 (Fig. 3). All years grouped for the southern zone shows a significant preference between $9.5-11^{\circ} \mathrm{C}$ due to the influence of the colder year of 2007.

A summary of the quotient analysis for the time series in northern zone (Fig. 4) show different significant peaks of the quotient (preferences) for every year. The years 2000, 2001, 2003 and 2006 do not shows any significant preferences. There is not a clear pattern for avoidance (quotient significantly $<1$ ). 

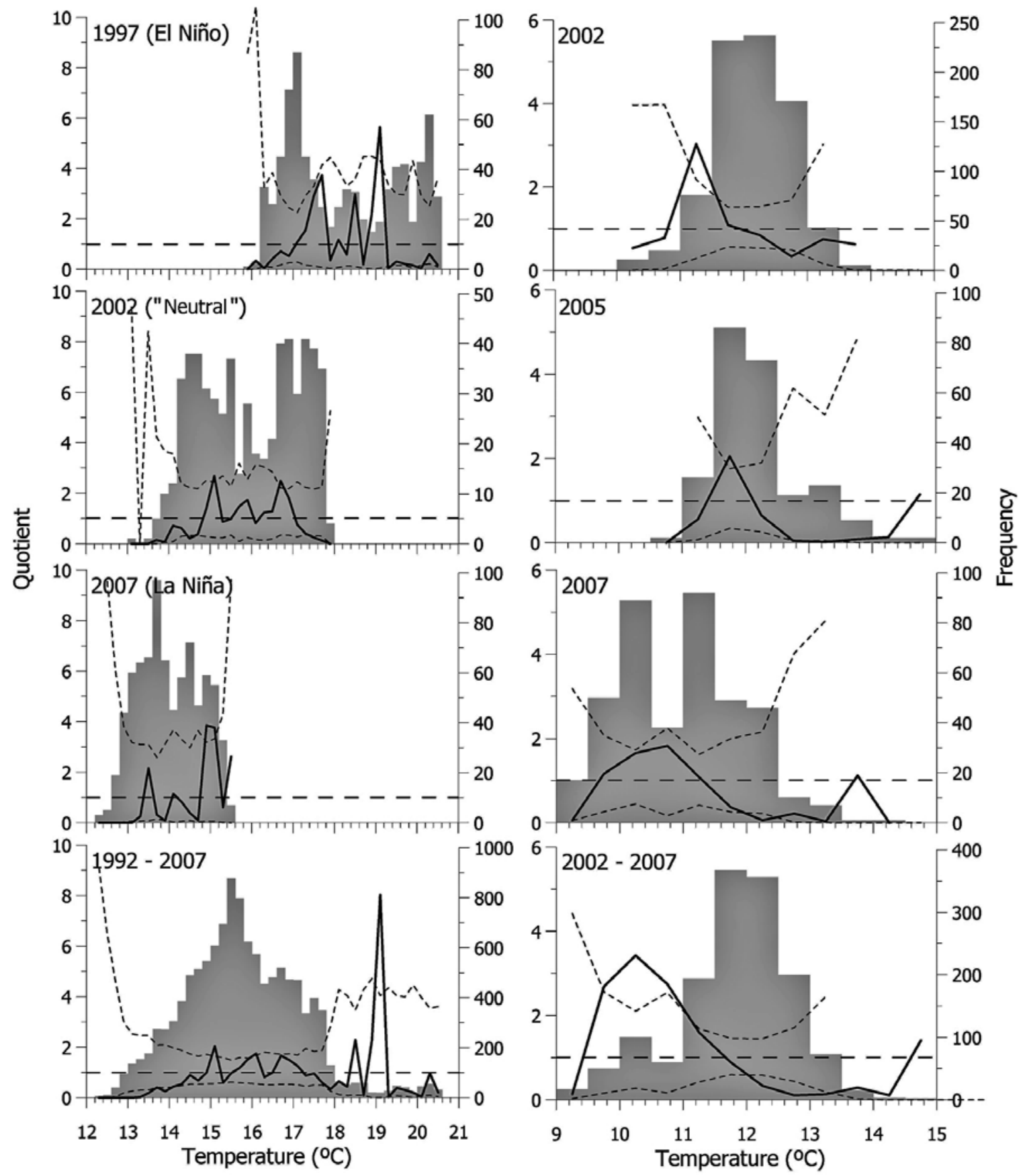

Figure 3. Quotient analysis for anchoveta egg distribution according to temperature in northern (left panels) and southern Chile (right panels) for three years of contrasting environmental conditions and the entire period analyzed (bottom). Grey areas show the number of observation (frequency) within each interval of temperature. The continuous line represents the egg concentration quotient value. Dashed lines represent its upper and lower confidence interval. The horizontal lines represents the null hypothesis of evenly distributed eggs (Quotient = 1) / Análisis del cuociente para la distribución de huevos de anchoveta en relación a la temperatura en el norte (paneles a la izquierda) y sur (paneles a la derecha) de Chile para tres años de condiciones ambientales contrastantes y para el período total analizado (abajo). Áreas grises muestran el número de observaciones (frecuencia) dentro de cada intervalo de temperatura. La línea continua representa el cuociente de la densidad de huevos. Líneas discontinuas representan el límite de confianza superior e inferior. La línea horizontal representa la hipótesis nula de huevos igualmente distribuidos (Cuociente $=1$ ) 


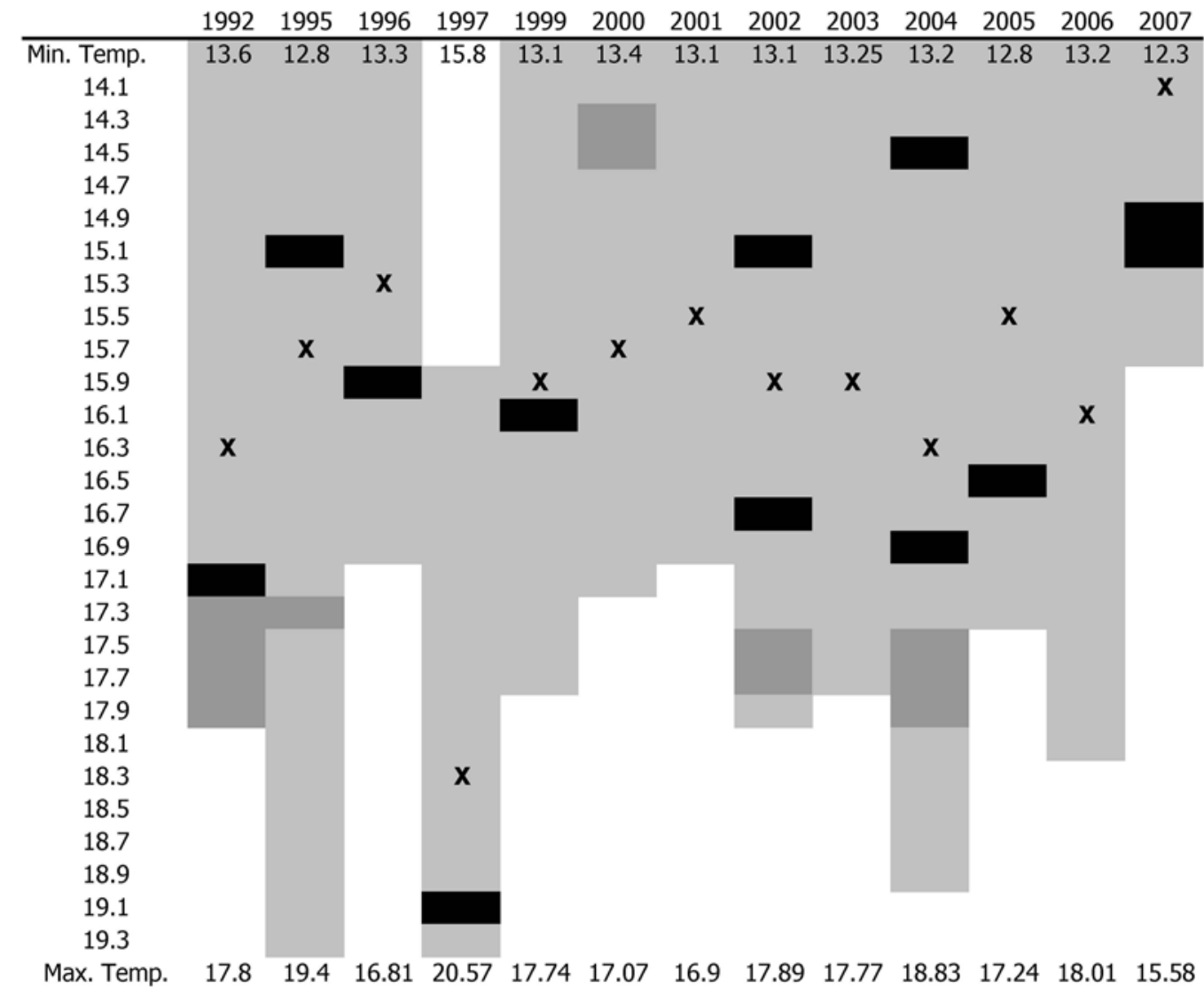

Figure 4. Results of the Quotient analysis for anchoveta egg distribution according to temperature in every survey in northern Chile. Black square represents significant preferences (Quotient $>1$ ). Dark grey rectangles represent significant avoidance (Quotient $<1$ ). Light grey shadow represent the temperature range (minimum and maximum temperature are showed). $X$ represents mean temperature of the survey / Resultados del análisis del cuociente para la distribución de huevos de anchoveta en relación a la temperatura en cada crucero en el norte de Chile. Cuadrados negros representan preferencias significativas (Cuociente $>1$ ). Rectángulos grises oscuros representan rechazos significativos (Cuociente $<1$ ). Gris claro muestra el rango de temperaturas (Se muestran la temperatura mínima y máxima). X representa la temperatura media del crucero

Thus, according to the results of quotient analyses for temperature, there is an inconsistency in the preferences for a temperature range by anchoveta females on an interannual scale.

The quotient analysis for chlorophyll- $a$ in the northern zone for the period 2004-2009 shows significant peaks at high levels of chlorophyll- $a$ (Fig. 5a). Because of the high asymmetry in the data, we carried out the same analysis but with the logarithm of the chlorophyll- $a$ data. The results shows a persistent preference for values higher than $0.6-0.8 \mathrm{mg} \mathrm{m}^{-3}$ (-0.25 to $-0.5 \mathrm{in} \ln$ ) (Fig. 5b).

The best GAM models applied to analyze the preferences, according to the deviance explained was
Eggs number $=s($ Latitude $)+s($ Longitude $)+s($ logarithm of Chl-a) (Table 2) with Poisson distribution and a link function log. Adding the Year and Temperature there is a increase of 0.2 and $4.2 \%$ of the explained deviance, respectively (Table 2). The plot of the smooth for Chl-a effect on eggs number shows similar result as quotient plot, a preference for higher concentration of Chl-a (Fig. $6)$.

\section{BATCH FECUNDITY}

The linear regression between body weight $(W)$ and batch fecundity ( $F$; Table 3 ) showed that in the 12 years analyzed in northern Chile, only in three years the intercept was 
Figure 5. Quotient analysis for anchoveta egg distribution according to chlorophyll-a concentration (satellite) in northern Chile (a) and with log transformed chlorophyll-a concentration (b). Grey areas show the number of observation (frequency) within each interval of chlorophyll. The continuous line represents the egg concentration quotient value. Dashed lines represent its upper and lower confidence interval. The horizontal lines represents the null hypothesis of evenly distributed eggs (Quotient $=$ 1) / Análisis del cuociente para la distribución de huevos de anchoveta en relación a la concentración de clorofila-a (satelital) en el norte de Chile (a) y con los valores de clorofila- $a$ transformados a logaritmo (b). Áreas grises muestran el número de observaciones (frecuencia) dentro de cada intervalo de clorofila-a. La línea continua es el valor del cuociente de la concentración de huevos. Líneas discontinuas representen el intervalo de confianza superior e inferior. La línea horizontal representa la hipótesis nula de huevos igualmente distribuidos (Cuociente $=1$ )
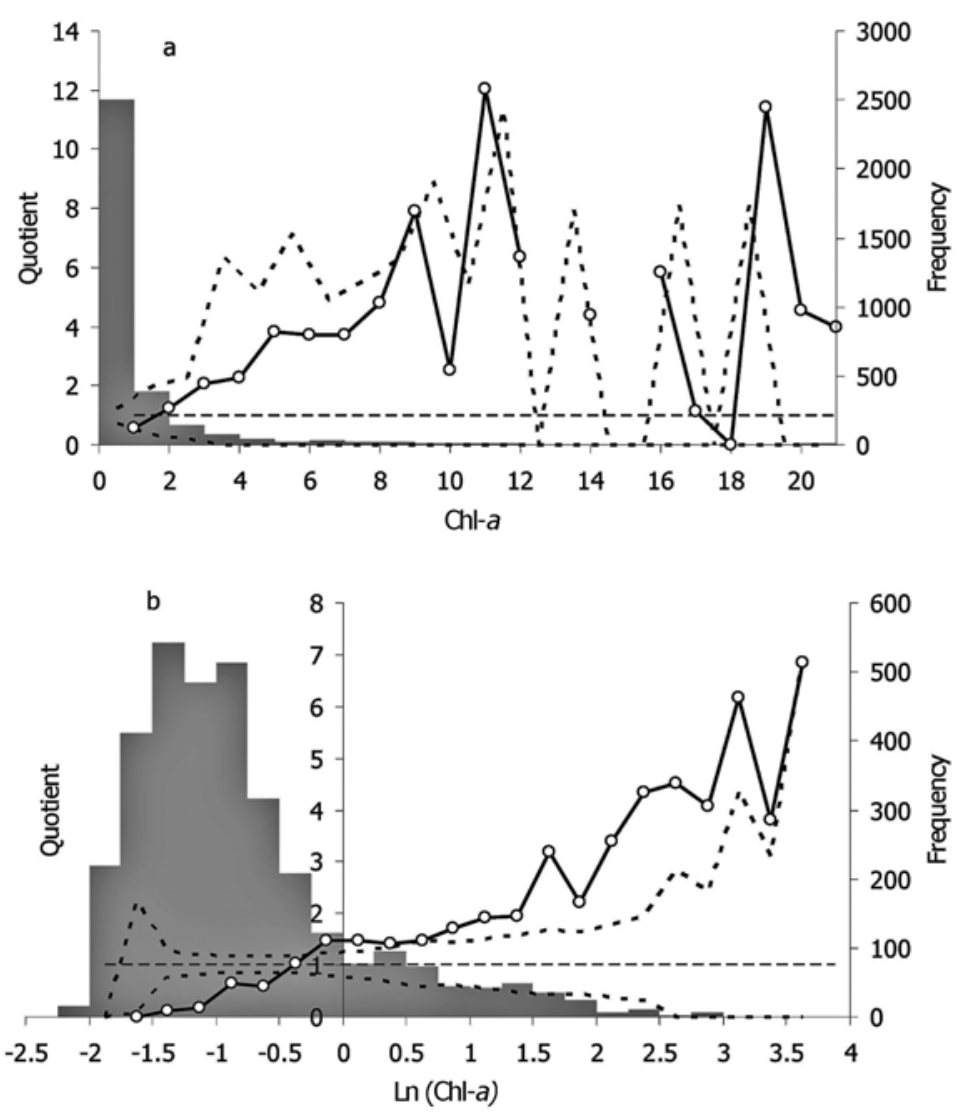

Figure 6. Plots of the smoothing response of the Generalized Additive Model for anchoveta spawning against chlorophyll-a concentration (satellite). Black thick line indicates the value of the GAM smoothing response and dotted lines represent the $95 \%$ confidence intervals / Respuesta suavizada del modelo aditivo generalizado para el desove de anchoveta en función de la concentración de clorofila- $a$ (satélite). Línea gruesa negra indica el valor de la respuesta del modelo (GAM) y líneas segmentadas representan el intervalo de confianza al $95 \%$

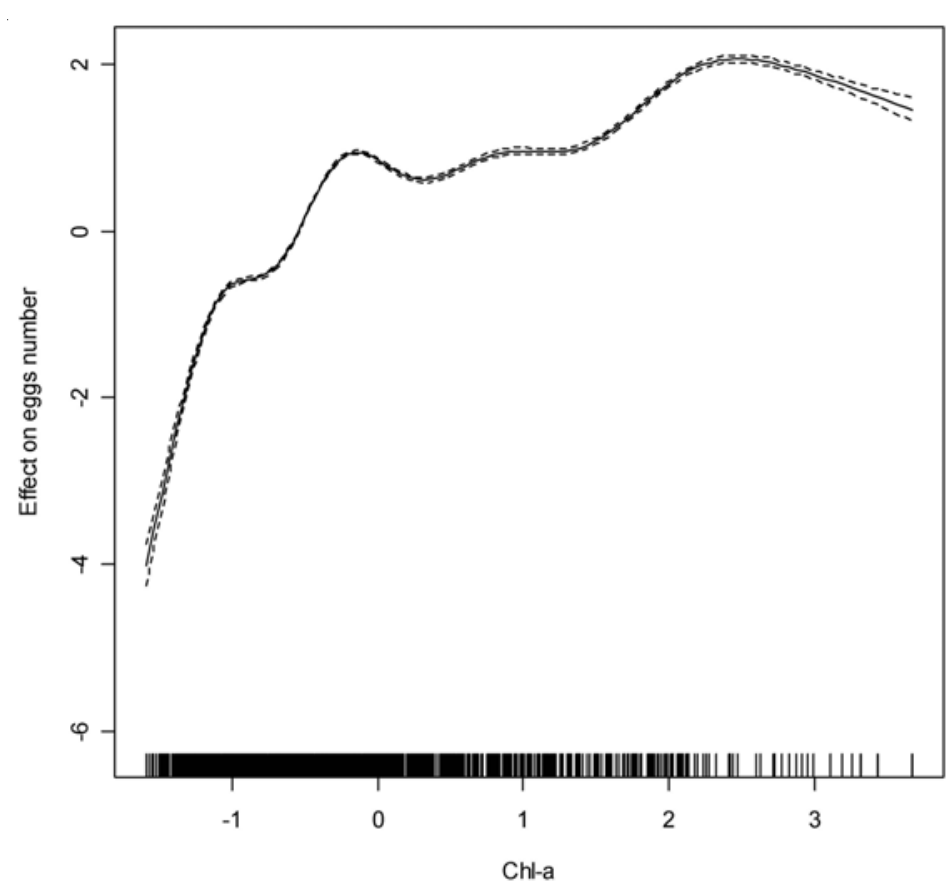


Table 2. Results of the generalized additive models (GAM). Intercept represents the overall mean, and s(Parameter) is the tensor product smoother. The standard error is shown in parenthesis. All parameters are significant. First column: Eggs number $=s($ Latitude $)+s($ Longitude $)+s($ logarithm of Chl-a). Second column: Same model more year. Third column: same model more temperature / Resultados del modelo aditivo generalizado (GAM). Intercepto representa la media y $s$ (Parámetro) es el suavizador. El error estándar es mostrado en paréntesis. Todos los parámetros son significativos. Primera columna: Número de huevos $=s($ Latitud $)+s($ Longitud $)+s($ logaritmo de Chla). Segunda columna es el mismo modelo más año. Tercera columna: mismo modelo más temperatura

\begin{tabular}{lccc} 
& 1 & 2 & 3 \\
\cline { 2 - 4 } & $1.97(0.0099)$ & $147.91(5.42)$ & $185.36(5.68)$ \\
Intercept & & $-0.073(0.0027)$ & $-0.091(0.0028)$ \\
Year & 8.912 & 8.912 & 8.884 \\
$\mathrm{~S}($ Latitude) & 8.784 & 8.784 & 8.714 \\
$\mathrm{~S}$ (Longitude) & 8.942 & 8.942 & 8.926 \\
$\mathrm{~s}($ log(Chl-a)) & --- & -- & 8.901 \\
$\mathrm{~S}($ Temperature $)$ & 0.057 & 0.054 & 0.0674 \\
$\mathrm{R}^{2}$ (adj) & 71.875 & 71.654 & 67.788 \\
UBRE score & $25.2 \%$ & $25.4 \%$ & $29.4 \%$ \\
Deviance explained & & & \\
\hline
\end{tabular}

Table 3. Parameters of the regression between body weight $(W)$ and batch fecundity $(F)$ for each year in northern and southern Chile. $S a$ and $S b$ : Standard error of parameter. $F=b^{*} W$ : Regression forced to the origin $(a=0)$. $\left({ }^{*}\right)$ : Intercept not significant different from zero $(P>0.05)$ / Parámetros de la regresión entre peso corporal $(W)$ y fecundidad parcial $(F)$ para cada año en el norte y sur de Chile. $S a$ y $S b$ : Errores estándar de los parámetros. $F=b^{*} W$ : Regresión forzada al origen $(a=0)$. $\left({ }^{*}\right)$ : Intercepto no significativamente distinto de cero $(P>0,05)$

\begin{tabular}{|c|c|c|c|c|c|c|c|c|}
\hline \multirow[b]{3}{*}{ Year } & \multicolumn{8}{|c|}{ Northern Chile } \\
\hline & \multicolumn{3}{|c|}{$\mathrm{F}=\mathrm{a}+\mathrm{b} * \mathrm{~W}$} & & \multirow[b]{2}{*}{$r^{2}$} & \multirow[b]{2}{*}{$\mathrm{n}$} & \multicolumn{2}{|c|}{$\mathrm{F}=\mathrm{b} * \mathrm{~W}$} \\
\hline & Intercept(a) & $\mathrm{S}_{\mathrm{a}}$ & Slope (b) & $\mathrm{S}_{\mathrm{b}}$ & & & Slope (b) & $\mathrm{S}_{\mathrm{b}}$ \\
\hline 1995 & $671.77\left(^{*}\right)$ & 1916.66 & 534.57 & 65.12 & 0.30 & 156 & 557.18 & 8.93 \\
\hline 1996 & $337.46(*)$ & 1514.08 & 690.51 & 55.68 & 0.59 & 107 & 702.69 & 10.63 \\
\hline 1997 & 6950.80 & 1923.85 & 262.61 & 78.30 & 0.05 & 210 & 543.16 & 10.35 \\
\hline 1999 & $105.44(*)$ & 816.02 & 498.60 & 34.12 & 0.54 & 187 & 502.85 & 8.90 \\
\hline 2000 & $-5127.08(*)$ & 3285.50 & 740.45 & 116.16 & 0.28 & 109 & 560.55 & 14.35 \\
\hline 2001 & $2205.21\left(^{*}\right)$ & 2097.95 & 465.10 & 69.02 & 0.26 & 133 & 536.77 & 10.70 \\
\hline 2002 & 11341.20 & 2719.11 & 259.56 & 121.04 & 0.06 & 69 & 761.07 & 15.52 \\
\hline 2003 & $-1237.67(*)$ & 1388.04 & 615.84 & 57.52 & 0.54 & 99 & 565.24 & 9.36 \\
\hline 2004 & $-4164.12(*)$ & 2944.92 & 584.18 & 120.27 & 0.20 & 96 & 414.75 & 10.38 \\
\hline 2005 & $1152.76(*)$ & 2582.87 & 431.29 & 86.79 & 0.24 & 79 & 469.74 & 10.61 \\
\hline 2006 & $-4476.16(*)$ & 2326.28 & 788.63 & 87.82 & 0.54 & 72 & 622.63 & 16.76 \\
\hline \multirow[t]{2}{*}{2007} & -4212.84 & 1688.05 & 726.94 & 74.06 & 0.57 & 76 & 544.00 & 10.93 \\
\hline & \multicolumn{8}{|c|}{ Southern Chile } \\
\hline 2002 & $-613.40(*)$ & 824.67 & 422.38 & 44.29 & 0.37 & 158 & 390.16 & 9.20 \\
\hline 2003 & $121.00\left(^{*}\right)$ & 580.50 & 395.12 & 34.07 & 0.58 & 100 & 401.89 & 10.97 \\
\hline 2004 & $600.21\left(^{*}\right)$ & 864.32 & 360.86 & 39.08 & 0.56 & 68 & 387.13 & 9.76 \\
\hline 2005 & $-311.16(*)$ & 677.80 & 331.17 & 40.18 & 0.76 & 23 & 313.89 & 13.82 \\
\hline 2007 & $-574.21(*)$ & 734.85 & 445.11 & 33.36 & 0.66 & 92 & 419.91 & 8.54 \\
\hline
\end{tabular}


significantly different from zero (1997, 2002 and 2007; t test; $P<0.05)$. For central Chile population Chile in all years the intercept was not different from zero (t test; $P>$ 0.05; Table 3). If the relationship between body weight and batch fecundity has intercept equal to cero, therefore the model is: $\mathrm{F}=b^{*} W$, which the slope is relative fecundity ( $\mathrm{N}^{\circ}$ oocytes per gram of body weight) and is independent of the female body weight. The confidence interval (95\%) of the slope (relative fecundity) for the central Chile population zone does not overlap with the northern population except 2004, indicating a significant lower relative fecundity in the central Chile population. When all years are pooled the slope of the relationship is significantly higher in the northern than in the central population ( $\mathrm{t}_{\text {calc }}: 3.76, P<0.05$ ) (Fig. 7), indicating a higher fecundity at the same female body weight. However, there is no significant difference $\left(\mathrm{t}_{\text {calc }}=1.38 ; P>0.05\right)$ in the slope of the relationship between body weight and ovary weight between populations (Fig. 7). A small difference was found between intercepts $(P<0.05)$, but for the northern zone these results have the risk of extrapolation of the regression lines far beyond the range of body weight (below $20 \mathrm{~g}$ ). Therefore, a female with the same body weight has the same ovary weight in both populations.

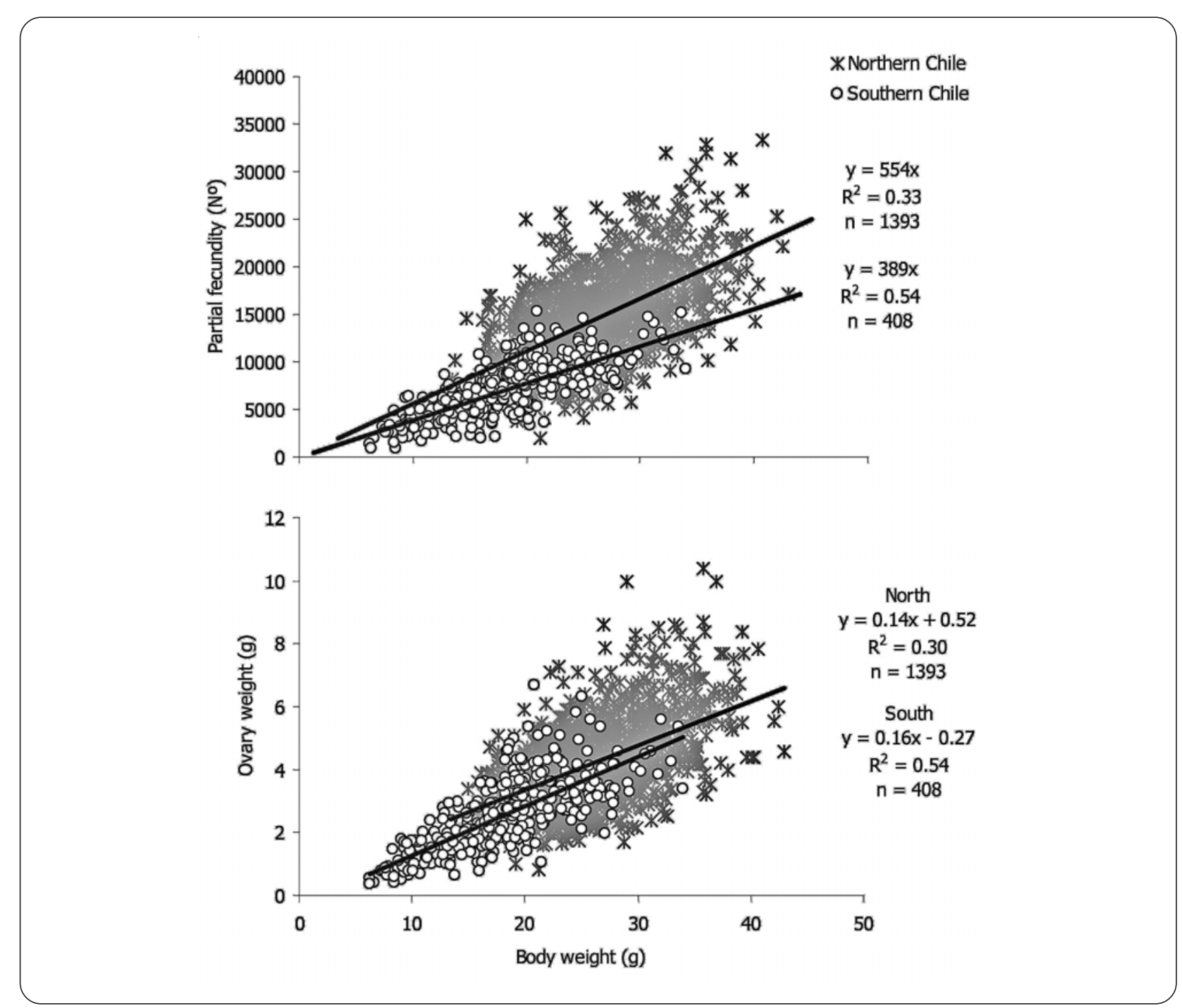

Figure 7. Relationships between body weight and batch fecundity (Top) and ovary weight (Bottom) for anchoveta of northern and southern Chile. All year pooled / Relación entre el peso corporal y la fecundidad parcial (Arriba) y con el peso del ovario (Abajo) para anchoveta del norte y sur de Chile. Todos los años agrupados 


\section{EGG SIZE}

In the northern zone, the volume of eggs collected in the plankton surveys showed a significantly negative relationship with temperature on the stations (10 $\mathrm{m}$ depth) in all years analyzed (Table 4$)$. The mean egg volume at temperature intervals $\left(0.5^{\circ} \mathrm{C}\right)$ pooled for all years showed a clear negative relationship (Fig. 8).

Interannually, the mean egg volume of the survey conducted in 2007 (La Niña) was higher in comparison to the other years analyzed, as a product of the colder temperatures (Fig. 9) and there is a significant effect of the mean temperatures on the mean diameter of the eggs collected in the surveys.

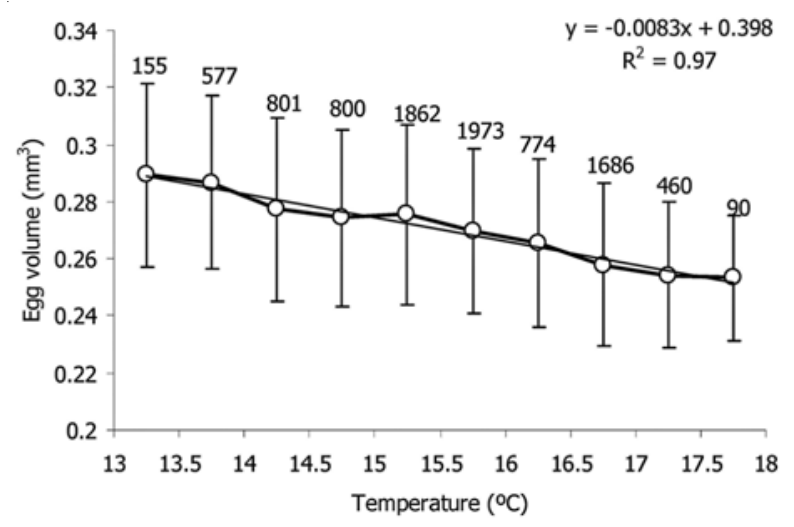

Figure 8. Mean of the egg volume $\left(\mathrm{mm}^{3}\right)$ at temperature intervals $(0.5 \circ \mathrm{C})$ for all year pooled $(2000,2001,2002,2003$ and 2007). Number of samples in each interval is indicated. Vertical lines: standard deviation / Volumen medio de los huevos $\left(\mathrm{mm}^{3}\right)$ a intervalos de temperatura $(0,5 \mathrm{O})$ para todos los años agrupados $(2000,2001,2002,2003$ y 2007). Se indica el número de muestras en cada intervalo. Líneas verticales: Desviación estándar

\section{SPAWNING FRACTION}

There is no evidence of a relationship between the mean temperature and daily spawning fraction (slope $=0.0037$; $\mathrm{t}_{\text {calc }}=0.906 ; P=0.38$ ) (Fig. 10).

\section{Discussion}

Our study shows that temperature is not a selected environmental variable to determine spawning sites in anchoveta. We postulate therefore, that instead of searching for certain temperatures, anchoveta accommodate their offspring characteristics (e.g., egg size, fecundity) according to the prevalent environment. The response of the reproductive system to temperature might be in the scale of spawning frequency, i.e., weeks. The selected environmental variable and that explains the changes in the localization and extension of the spawning sites would be the high chlorophyll concentrations.

\section{REgIONAL DISTRIBUTION OF SPAWNING AREAS}

According to Castillo-Jordán et al. (2007), the main spawning area in the southern zone is restricted to the more coastal zone. Usually, it occurs in waters with $<75$ $\mathrm{m}$ water depth and peaks at around $50 \mathrm{~m}$ water depth. GAM models (Castillo-Jordán et al. 2007) indicate that in southern Chile egg density distribution was better explained by a bivariate function of longitude and latitude together with bottom depth. However, since in this case egg densities depend exclusively on parameters that are not directly sensitive for fish, the results are not satisfactory from a biological point of view (CastilloJordán et al. 2007). These authors attribute the fact that sea surface temperature was not significantly related to

Table 4. Parameters of the regression between temperature (10 $\mathrm{m}$ depth) and the egg volume of each station for 5 years. $S a$ and $S b$ : Standard error of parameter. Ho: $b=0$ : Probability that slope $=0$ / Parámetros de la regresión entre temperatura ( $10 \mathrm{~m}$ de profundidad) y el volúmen de los huevos en cada estación para 5 años. $S a$ y $S b$ : Errores estándar de los parámetros. Ho: $\mathrm{b}=0$ : Probabilidad que la pendiente $=0$

\begin{tabular}{lccccc} 
& 2000 & 2001 & 2002 & 2003 & 2007 \\
\cline { 2 - 6 } & 0.46 & 0.34 & 0.31 & 0.35 & 0.40 \\
Intercept(a) & 0.021 & 0.011 & 0.010 & 0.011 & 0.015 \\
$\mathrm{Sa}$ & -12.13 & -4.19 & -3.39 & -5.73 & -7.67 \\
Slope (b)*10-3 & 1.345 & 0.718 & 0.645 & 0.711 & 1.018 \\
$\mathrm{Sb}^{*} 10^{-3}$ & $8.05^{*} 10^{-19}$ & $6.10^{*} 10^{-9}$ & $1.57^{*} 10^{-7}$ & $2.92 * 10^{-15}$ & $7.16^{*} 10^{-14}$ \\
$\mathrm{Ho}: \mathrm{b}=0$ & 0.066 & 0.013 & 0.010 & 0.080 & 0.026 \\
$\mathrm{r}^{2}$ & 1148 & 2496 & 2693 & 747 & 2094 \\
$\mathrm{n}$ & & & & & \\
\hline
\end{tabular}




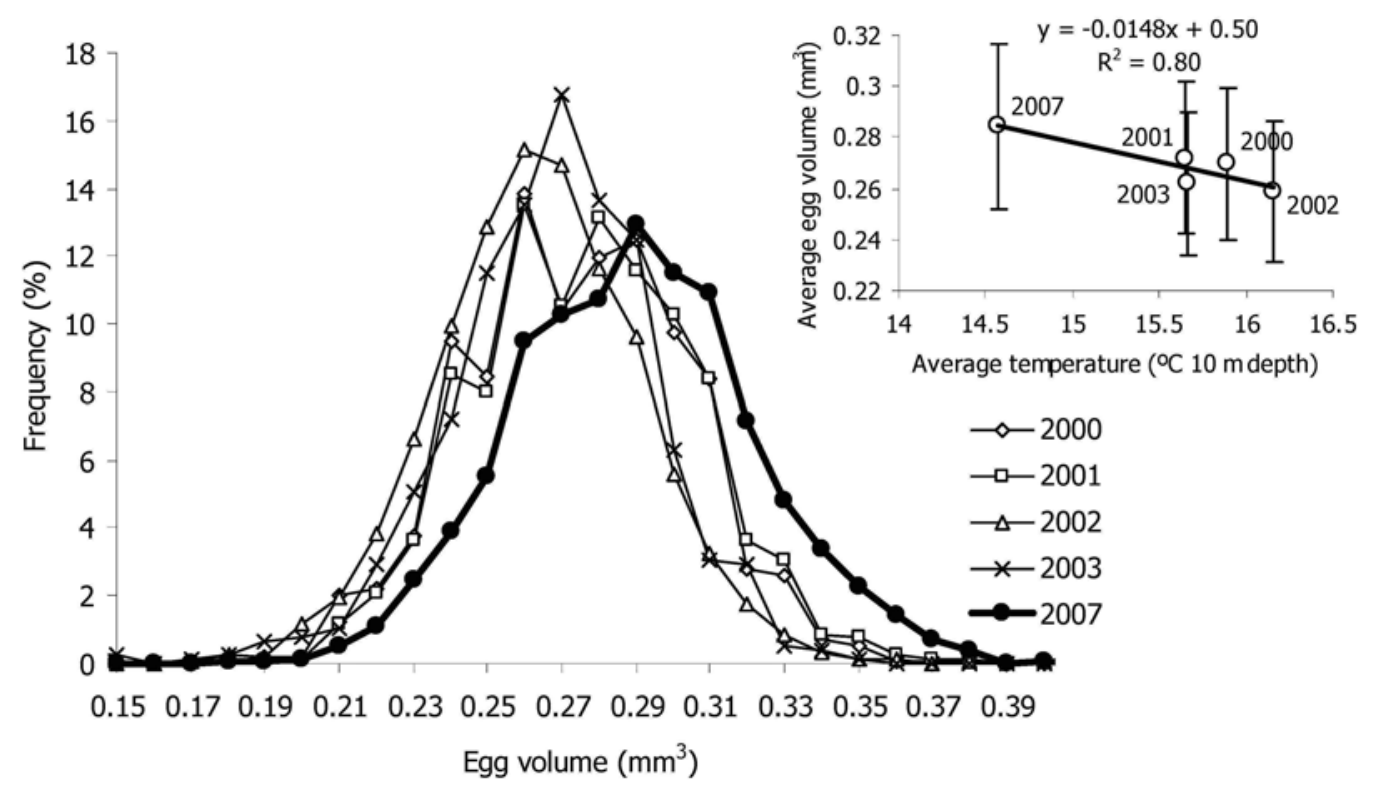

Figure 9. Eggs volume frequency distribution for surveys from 2000 to 2003 and 2007 . Small figure is the relationship between survey average of temperature and egg volume (Vertical lines: standard deviation; year is indicated for each point) / Distribución de frecuencia del volumen de los huevos para los cruceros del 2000 al 2003 y 2007 . Figura pequeña es la relación entre el promedio de la temperatura y del volumen de los huevos (Línea vertical: Desviación estándar; Se indica el año para cada punto)

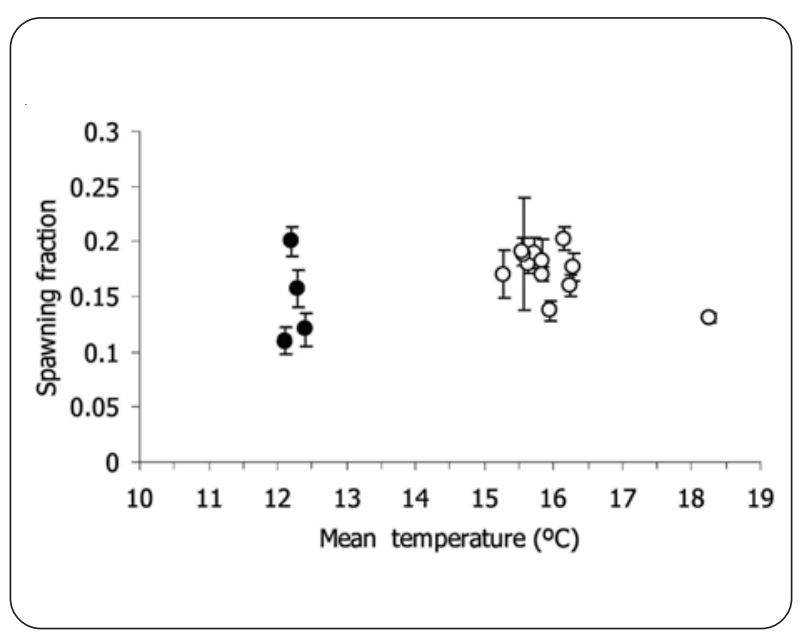

Figure 10. Relationship between mean temperature of the survey and daily spawning fraction in anchoveta of northern (Open circles) and southern (Solid circles) Chile / Relación entre la temperatura media del crucero y la fracción diaria de hembras desovantes en anchoveta del norte (círculos blancos) y sur (círculos negros) de Chile the egg distribution of anchoveta to the narrow temperature range during their survey $\left(11^{\circ}\right.$ to $\left.13^{\circ} \mathrm{C}\right)$ and speculate that this temperature range may represent the optimum for spawning. Bustos et al. (2008) found for Engraulis ringens inhabiting fjords in the most southern region of Chile, the presence of spawning associated to zones with highly stratified waters, which may increase the vertical aggregation of the plankters and promote feeding success of larvae. But, fjord zone of Chile has an ocean dynamics quite different from the coastal area of northern and central Chile, where upwelling events dominate the coastal ecosystem. For northern populations there is no explanation yet for the changes in the location of their spawning areas. As they are located in oceanic regions with thousands of meters water depth, they cannot be used as explanatory variable in models as in the southern zone.

Chlorophyll- $a$ appears as a selected environmental variable for spawning habitat, similar as founded by Schismenou et al. (2008) for Engraulis encrasicolus, probably because chlorophyll concentration is generally accepted as a good indicator of primary production (Longhurst et al. 1995) and food availability (Basilone et 
al. 2004), and it is related with fish biomass production (Iverson 1990). Yañez-Rubio et al. (2011) indicates for anchoveta larvae a high feeding incidence with a mixed diet initially dominated by phytoplankton (small larvae) and later switching to zooplankton preys (older larvae). Basilone et al. (2004) observed a significant relationship between chlorophyll concentration derived from satellite images and anchovy growth in the Mediterranean Sea, indicating that sea surface estimates of chlorophyll concentration are good indicators of food availability for anchovy, and Basilone et al. (2006) show that anchovy spawning intensity and condition factor were affected by chlorophyll concentration.

One restriction of this study and the GAM modeling is that chlorophyll satellite estimations were not validated with in situ information. Silva et al. (2000) showed that SeaWiFS chlorophyll estimations were overestimated in the Chilean coastal upwelling, in comparison with in situ data (approximately 2.3 times higher). The real values can therefore be considerably different from those derived from satellite images, but the latter are still useful for comparative studies of intra- and inter-annual chlorophyll concentration (Basilone et al. 2006) and for modeling the spawning in relation to easily accessible environmental information (Schismenou et al. 2008).

Other aspect to consider, is that the delineation of spawning habitat based on the abundance of spawning products, identifies realized spawning habitat (i.e., habitat where spawning actually occurs), and can be used to demarcate potential spawning habitat (i.e., where the hydrological and/or physical conditions are suitable for spawn), but cannot identify successful spawning habitat (i.e., from where successful recruitment has resulted) (Castro et al. 2005).

\section{BATCH FECUNDITY}

The relationships between body weight and batch fecundity have intercepts significantly different from zero only in years under the influence of ENSO events like the El Niño 1997 and 2002, or the La Niña 2007. The differences in the intercepts indicate higher or lower relative fecundity (number of oocytes per gram of body weight) as compared with 'normal' years (Neutral ENSO), when the intercept is zero and variations in the relative fecundity between years appear much smaller. Thus, relative fecundity is constant over the range of female weights in 'neutral' years. For Engraulis encrasicolus, Motos (1996) found that years with negative intercept coincided with high levels of recruitment and consequently high number of small 1 year old individuals at sea. According to our results, the interannual changes in the body weight-fecundity relationship are related to the temperature of the environment, which affects the egg size. The effect of female size is discarded according to the work of Leal et al. (2009) who demonstrated that oocyte volume in $E$. ringens was not significantly correlated with female length or weight from northern and southern Chile. Therefore, at the same size and ovary weight, females produce larger eggs in a cold rather than in a warm environment, but with a lower fecundity.

\section{EGG SIZE}

Variations in egg size among populations located along a latitudinal gradient or during the spawning season have been reported for a number of demersal and pelagic fishes (Blaxter \& Hempel 1963, Bagenal 1971, Blaxter \& Hunter 1982, Chambers 1997, Castro et al. 2002, Bustos et al. 2008, Castro et al. 2009). In general, larger eggs are spawned at higher latitudes, egg size tends to decrease as the spawning season progresses, and eggs produced in winter are larger than those spawned in summer (Ciechomski 1973, Clarke 1989, Claramunt et al. 1994, Rijnsdorp \& Vingerhoed 1994, Chambers \& Waiwood 1996, Plaza et al. 2002, Llanos-Rivera \& Castro 2004, Rideout et al. 2005, Bustos et al. 2008, Leal et al. 2009). It has long been documented that larger eggs usually produce larger and more robust larvae capable of searching larger volumes of water for food, evading predators more successfully, or growing faster. All these characteristics should reduce mortality under adverse environmental conditions (Marteinsdottir \& Steinarsson 1998). Whereas most authors have proposed egg size variability to be an adaptive trait to enhance offspring survival under different environmental conditions, others have suggested that egg size variation may result from changing environmental temperature and hence, not necessarily represent an adaptive genetic response to facilitate offspring survival in different environments (Daoulas \& Economou 1986). Our results of an increase in egg size in the cold year 2007 as compared with 'neutral' years with neutral ENSO, indicates that the temperature regime (along with its associated factors such as the food quality, see below; Castro et al. 2009) induces changes in the reproductive system which determines egg size (phenotypic plasticity), probably to enhance offspring survival. Furthermore, if schools of anchoveta are moving around the environment, our results of a significant relationship between the temperature at a station and egg 
volume in the plankton in all years analyzed, means that females are responding to the prevalent temperature on the temporal scale of their spawning frequency (each 5 to 10 days), i.e., in the scale of weeks. Previous reports indicated that the environmental temperature during the 90 to 60 days before spawning might have an important effect on fish fecundity and egg size (Tanasichuk \& Ware 1987, Leal et al. 2009). Also, the differences in the yolked mode between northern and southern populations indicate that the oocyte size is determined during early vitellogenesis, as found by Plaza et al. (2002) in Sardinops sagax from northern Chile. For this species, reports also show that the initial differences in egg size between the northern and southern populations off Chile propagate to the following exogenous-feeding larval stage (post yolk sac larvae) (Llanos-Rivera \& Castro 2006). In both populations, initial winter egg sizes were highly correlated with larval length at hatching, yolk sac volume at hatching, and larval length at yolk absorption; all these traits may positively affect the survival chances of the young larvae. Castro et al. (2009) also show that hatching success is higher in the southern than northern population, associated with the size of the eggs and higher lipid content. According to these authors, in periods during the reproductive season when egg quality is high (i.e., larger and high lipid contents), hatching success is also high, independent of the geographic distribution of the population. Larger sized eggs have also been observed to have different fatty acids proportions, indicative of better quality and of variations in the female's feeding environment (Castro et al. 2010). These results are particularly interesting when considering inter-annual variations, and they might explain the abrupt changes in recruitment observed from one year to another despite large reductions in biomass (Castro et al. 2009).

\section{SPAWNING FRACTION}

Claramunt et al. (2007) report a relationship between female size and spawning fraction in E. ringens from northern and southern Chile, but did not find a clear influence of temperature. In the present study, no relationship was observed between temperature and spawning fraction. Fitzhugh \& Hettler (1995) report a reduction of postovulatory follicle duration of approximately $24 \mathrm{~h}$ with an increase of temperature by $4^{\circ} \mathrm{C}$. Accordingly, some of the observations at higher temperatures might be indicative of potential problems in the aging of postovulatory follicles (i.e., during El Niño) rather than the spawning fraction (Claramunt et al. 2007). Alday et al. (2008) report a minimal influence of temperature on the degeneration of POFs for Engraulis encrasicolus at the range of temperatures covered, basically between 13 and $19^{\circ} \mathrm{C}$. Therefore, more research is needed to understand the effect of temperature on the degeneration of the postovulatory follicle stages (Claramunt et al. 2007, Alday et al. 2008).

\section{ACKnowledgments}

Funding for the present study was provided by the 'Fondo de Investigación Pesquera' and FONDECYT (Grants 1100534) to Leonardo Castro and Gabriel Claramunt.

\section{LITERATURE CITED}

Alday A, A Uriarte, M Santos, I Martín, A Martinez \& L Motos. 2008. Degeneration of postovulatory follicles of the Bay of Biscay anchovy (Engraulis encrasicolus L.). Scientia Marina 72(3): 565-575.

Alheit J, V Alarcón \& B Macewicz. 1984. Spawning frequency and sex ratio in the peruvian anchovy, Engraulis ringens. CALCOFI Reports 25: 43-52.

Bagenal T. 1971. The interrelation of the size of fish eggs, the date of spawning and the production cycle. Journal of Fish Biology 3: 207-219.

Basilone G, C Guisande, B Patti, S Mazzola, A Cuttita, A Bonanno \& A Kallianotis. 2004. Linking habitat conditions and growth in the European anchovy (Engraulis encrasicolus). Fisheries Research 68: 9-19.

Basilone G, C Guisande, B Patti, S Mazzola, A Cuttitta, A Bonanno, A Vergara \& I Maneiro. 2006. Effect of habitat conditions on reproduction of the European anchovy (Engraulis encrasicolus) in the Strait of Sicily. Fisheries Oceanography 15(4): 271-280.

Bernal M, Y Stratoudakis, S Coombs, M Angelico, A Lago de Lanzós, C Porteiro, Y Sagarminaga, M Santos, A Uriarte, E Cunha, L Valdés \& D Borchers. 2007. Sardine spawning off the European Atlantic coast: Characterization of and spatio-temporal variability in spawning habitat. Progress in Oceanography 74: 210-227.

Blaxter J \& G Hempel. 1963. The influence of egg size on herring larvae (Clupea harengus). Journal du Conseil / Conseil Permanent Internationl pour l'Exploration de la Mer 28: 211-240.

Blaxter J \& J Hunter. 1982. The biology of clupeoid fishes. Advances in Marine Biology 20: 1-223.

Bustos CA, MF Landaeta \& F Balbontín. 2008. Spawning and early nursery areas of anchoveta Engraulis ringens Jenyns, 1842 in fjords of southern Chile. Revista de Biología Marina y Oceanografía 43(2): 381-389. 
Castillo-Jordán C, LA Cubillos \& J Paramo. 2007. The spawning spatial structure of two co-occurring small pelagic fish off central southern Chile in 2005. Aquatic Living Resources 20: 77-84.

Castro LR, G Salinas \& EH Hernández. 2000. Environmental influences on winter spawning of the anchoveta, Engraulis ringens, off Central Chile. Marine Ecology Progress Series 197: 247-258.

Castro LR, A Llanos-Rivera, JL Blanco, E Tarifeño, R Escribano \& M Landaeta. 2002. Latitudinal variations in spawning habitat characteristics: influence on the early life history traits of the anchoveta, Engraulis ringens, off northern and central Chile. GLOBEC Report 16: 42-45.

Castro LR, P Fréon, C van der Lingen \& A Uriarte. 2005. Recommendations from the discussion session: Characterizing spawning habitat. Report of the SPACC Meeting on Small Pelagic Fish Spawning Habitat Dynamics and the Daily Egg Production Method (DEPM). GLOBEC Report 22: 1-107.

Castro LR, G Claramunt, MC Krautz, A Llanos-Rivera \& P Moreno. 2009. Egg trait variation in anchoveta Engraulis ringens: a maternal response to changing environmental conditions in contrasting spawning habitats. Marine Ecology Progress Series 381: 237-248.

Castro LR, G Claramunt, HE González, MC Krautz, A Llanos-Rivera, J Méndez, W Schneider \& S Soto. 2010. Fatty acids in eggs of anchoveta Engraulis ringens during two contrasting winter spawning seasons. Marine Ecology Progress Series 420: 193-205.

Chambers R. 1997. Environmental influences on egg and propagule sizes in marine fishes. In: Chambers RC \& EA Trippel (eds). Early life history and recruitment of fish populations, pp 63-102. Chapman \& Hall, London.

Chambers R \& K Waiwood. 1996. Maternal and seasonal differences in egg sizes and spawning characteristics of captive Atlantic cod, Gadus morhua. Canadian Journal of Fisheries and Aquatic Sciences 53: 1986-2003.

Ciechomski J. 1973. The size of the egg of the Argentine anchova Engraulis anchoita in relation to the season of the year of spawning. Journal of Fish Biology 5: 393-398.

Claramunt G, G Herrera \& P Pizarro. 1994. Producción potencial anual de huevos por tallas en Sardinops sagax (Jenyns, 1842) del norte de Chile. Revista de Biología Marina 29(2): 211-233.

Claramunt G, R Serra, L Castro \& L Cubillos. 2007. Is the spawning frequency dependent on female size? Empirical evidence in Sardinops sagax and Engraulis ringens off northern Chile. Fisheries Research 85: 248-257.

Clarke T. 1989. Seasonal differences in spawning, egg size, and early development time of the hawiian anchovy of nehu, Encrasicholina purpurea. Fishery Bulletin 87(3): 593-600.
Daoulas C \& A Economou. 1986. Seasonal variation of egg size in the sardine, Sardina pilchardus Walb., of the Saronikos Gulf: causes and a probable explanation. Journal of Fish Biology 28: 449-457.

Drapeau L. 2004. Introduction to the use of quotient curves for characterizing spawning habitat of small, pelagic fish. In: Van der Lingen CD, L Castro, L Drapeau \& D Checkley (eds). Report of a GLOBEC-SPACC Workshop on Characterizing and conmparing the spawning habitat of small pelagic fish. GLOBEC Report 21: 5-6.

Fitzhugh G \& W Hettler. 1995. Temperature influence on postovulatory follicle degeneration in Atlantic menhaden, Brevoortia tyrannus. Fishery Bulletin 93(3): 568-572

Hernández EH \& LR Castro. 2000. Larval growth of the anchoveta Engraulis ringens during the winter spawning season off central Chile. Fishery Bulletin 98: 704-710.

Hunter J \& B Macewicz. 1985. Measurement of spawning frequency in multiple spawning fishes. In: Lasker R (ed). An egg production method for estimating spawning biomass of pelagic fish: application to the northern anchovy, Engraulis mordax. NOAA Technical Report NMFS 36: 79-94.

Hunter J, N Lo \& R Leong. 1985. Batch fecundity in multiple spawning fishes. In: Lasker R (ed). An egg production method for estimating spawning biomass of pelagic fish: Application to the northern anchovy, Engraulis mordax. NOAA Technical Report NMFS 36: 67-77.

Leal E, L Castro \& G Claramunt. 2009. Variability in oocyte size and batch fecundity in anchoveta (Engraulis ringens, Jenyns 1842) from two spawning areas off the Chilean coast. Scientia Marina 73(1): 59-66.

Llanos-Rivera A \& LR Castro. 2004. Latitudinal and seasonal egg size variations of the anchoveta Engraulis ringens off the Chilean Coast. Fishery Bulletin 102: 207-212.

Llanos-Rivera A \& LR Castro. 2006. Inter-population differences in temperature effects on Engraulis ringens yolk-sac larvae. Marine Ecology Progress Series 312: 245253.

Longhurst AR, S Sathyendranath, T Platt \& C Cavehill. 1995. An estimate of global primary production in the ocean from satellite radiometer data. Journal of Plankton Research 17: $1245-1271$.

Marteinsdottir G \& A Steinarsson. 1998. Maternal influence on the size and viability of Icelandic cod Gadus morhua eggs and larvae. Journal of Fish Biology 52: 1241-1258.

Motos L. 1996. Reproductive biology and fecundity of the Bay of Biscay anchovy population (Engraulis encrasicolus L.). Scientia Marina 60(2): 195-207.

Plaza G, G Claramunt \& G Herrera. 2002. An intra-annual analysis of intermediate fecundity, batch fecundity and oocyte size of ripening ovaries of Pacific sardine Sardinops sagax in northern Chile. Fisheries Science 68: 95-103. 
Rideout R, E Trippel \& M Litvak. 2005. Effects of egg size, food supply and spawning time on early life history success of haddock Melanogrammus aeglefinus. Marine Ecology Progress Series 285: 169-180.

Rijnsdorp A \& B Vingerhoed. 1994. The ecological significance of geographical and seasonal differences in egg size in Solea solea (L.). Netherland Journal of Sea Research 32(3/4): 255-270.

Schismenou E, M Giannoulaki, V Valavanis \& S Somarakis. 2008. Modeling and predicting potential spawning habitat of anchovy (Engraulis encrasicolus) and round sardinella (Sardinella aurita) based on satellite environmental information. Hydrobiologia 612: 201-214.

Serra R. 1986. Desarrollo de la pesquería de anchoveta (Engraulis ringens) y los cambios de su abundancia. Investigación Pesquera 33: 13-24.

Silva C, E Yañez, M Barbieri, K Nieto, V Mimica, F Espindola \& $\mathbf{J}$ Acevedo. 2000. Exploring the association between small pelagic fisheries and SeaWiFS chlorophyll and AVHRR sea surface temperature in the North of Chile. Sixth International Conference on Remote Sensing for Marine and Coastal Environments, Charleston, South Carolina, USA. ERIM International 2: 81-88.

Sobarzo M, L Bravo, D Donoso, J Garcés-Vargas \& W Schneider. 2007. Coastal upwelling and seasonal cycles that influences the water column over the continental shelf off central Chile. Progress in Oceanography 75(3): 363382.

Tanasichuk R \& D Ware. 1987. Influence of interannual variations in winter sea temperature on fecundity and egg size in Pacific herring (Clupea herengus pallasi). Canadian Journal of Fisheries and Aquatic Sciences 44: 1485-1495.

Thiel M, E Macaya, E Acuña, W Arntz, H Bastias, K Brokordt, P Camus, J Castilla, L Castro, M Cortes, P Clement, R Escribano, M Fernandez, J Gajardo, C
Gaymer, I Gomez, A Gonzalez, H Gonzalez, P Haye, J Illanes, J Iriarte, D Lancelloti, G Luna-Jorquera, C Luxoro, P Manriquez, V Marin, P Muñoz, S Navarrete, E Perez, E Poulin, J Sellanes, H Sepulveda, W Stotz, F Tala, A Thomas, C Vargas, J Vasquez \& J Vega. 2007. The Humboldt Current System of northern and central Chile. Oceanographic processes, ecological interactions and socioeconomic feedback. Oceanography and Marine Biology: An Annual Review 45: 195-344.

Valdivia I, R Chávez \& M Oliva. 2007. Metazoan parasites of Engraulis ringens as a tool for stock discrimination along the Chilean coast. Journal of Fish Biology 70: 1504-1511.

Van der Lingen $\mathrm{C}$, L Hutchings, D Merkle, J van der Westhuizen \& J Nelson. 2001. Comparative spawning habitats of anchovy (Engraulis capensis) and sardine (Sardinops sagax) in the southern Benguela upwelling ecosystem. In: Kruse GH, N Bez, T Booth, M Dorn, S Hills, RN Lipcius, D Pelletier, C Roy, SJ Smith \& D Witherell (eds). Spatial processes and management of marine populations, pp. 185-209. University of Alaska Sea Grant, Fairbanks.

Wright P \& E Trippel. 2009. Fishery-induced demographic changes in the timing of spawning: consequences for reproductive success. Fish and Fisheries 10: 283-304.

Yáñez E, S Hormazábal, C Silva, A Montecinos, M Barbieri, A Valdenegro, A Ordenes \& F Gómez. 2008. Coupling between the environment and the pelagic resources exploited off northern Chile: ecosystem indicators and a conceptual model. Latin American Journal of Aquatic Research 36(2): 159-181.

Yañez-Rubio A, A Llanos-Rivera, LR Castro, G Claramunt \& L Herrera. 2011. Variations in type, width, volume and carbon content of anchoveta Engraulis ringens food items during the early larval stages. Journal of the Marine Biological Association of the United Kingdom 91(6): 12071213.

Received 17 January 2012 and accepted 28 May 2012

Associate Editor: Mauricio Landaeta D. 